\title{
Consanguinity and its effect on fetal growth and development: a south Indian study
}

\author{
M L Kulkarni, Mathew Kurian
}

\begin{abstract}
The effect of consanguinity on fetal growth and development was studied in 3700 consecutive births (live and stillborn); $26 \%$ of the total births were to consanguineous couples. Hindus had a higher frequency of consanguineous marriages, uncle-niece unions being the commonest type, whereas Moslems preferred first cousin marriages. The incidence of congenital malformations was $39 \cdot 1 / 1000$ births with a significantly higher incidence among the consanguineous group $(8 \cdot 01 \%)$ as against the nonconsanguineous group $(2.42 \%)(p<0.001)$. The incidence of malformations was higher in the uncleniece matings $(9 \cdot 34 \%)$ compared to the first cousin marriages $(6.18 \%)(p<0.01)$. Malformations of major systems were significantly more frequent among the consanguineous couples, whereas malformations of the eyes, ears, and skin did not show any significant effect of consanguinity. Stillbirth rates were significantly higher in the consanguineous group, irrespective of the mother's socioeconomic status, and were higher in uncle-niece matings compared to first cousin and beyond first cousin unions in both the poor and middle/upper class. A significant decrease in the mean birth weight and head circumference of babies born to consanguineous parents was noted in both the poor and middle/upper socioeconomic class. The mean length was less in babies born to consanguineous parents belonging to the poor social class only.
\end{abstract}

South India provides a natural laboratory for the study of the effects of consanguinity on fetal growth in a population that has practised it for over 2000 years. ${ }^{1}$ There have been conflicting reports on the effect of consanguinity on fetal growth, some studies suggesting it has an adverse effect, ${ }^{2}$ others showing it has no

Department of Pediatrics, JJM Medical College, Davangere-577 004, Karnataka, India.

M L Kulkarni, M Kurian

Correspondence to Professor Kulkarni, Shriram Prasad, P J Extension, Davangere-577 004, Karnataka, India.

Received for publication 20 February 1989.

Revised version accepted for publication 4 December 1989. effect, ${ }^{3}$ and still others showing that it has a beneficial effect if practised over a long period of time. ${ }^{4}$ In the present study, consanguinity and its effects on fetal growth and development were studied in Davangere, a south Indian city.

\section{Materials and methods}

A total of 3700 consecutive live and stillbirths took place at three hospitals between November 1985 and March 1987. They were examined within 24 hours of birth for evidence of congenital malformations, and their growth parameters (weight/length/head circumference) were assessed by standard anthropometric techniques. ${ }^{5}$ Mothers were questioned about their obstetric history, parental consanguinity, and socioeconomic class. Social class was graded according to the classification of Prosad, ${ }^{6}$ suitable for Indian standards. Groups I to III of Prosad's classification were included in the middle/upper class and groups IV and V in the poor socioeconomic class. Nearly $50 \%$ of all births in this area took place in these hospitals. The socioeconomic and religious distribution of these mothers did not differ from the local population.

A pedigree extending to a minimum of three generations was drawn in all the cases and an attempt was made to draw a further extended pedigree in families where mothers indicated consanguinity. However, we experienced difficulty in drawing very large pedigrees because of the ignorance of mothers. Necropsies were done in a few cases; however, in none of them did it change the primary diagnosis.

Necropsies were carried out on all babies who were stillborn with neural tube defects (NTD) and on those born alive with NTD but who subsequently died in the neonatal period, as this formed the subject of another study. Of the 44 central nervous system malformations (43 NTDs and one Meckel-Gruber syndrome), 31 were subjected to necropsy. Three cases of anencephaly had hydronephrosis, seven had pulmonary hypoplasia, and one had bicornuate uterus. Diaphragmatic hernia was seen in a case of iniencephaly as well as in a case of meningomyelocele. A case of Meckel-Gruber syndrome and a case of Jeune's asphyxiating thoracic dystrophy had cystic dysplastic kidneys. A child with a white forelock, blue irides, and a pigmentary disorder of skin, inherited as 
Table 1 Distribution of consanguineous matings among different religious groups.

\begin{tabular}{lccccccccc}
\hline Religion & Total & Consanguineous & $\%$ & U-N & $\%$ & FC & $\%$ & BYFC & $\%$ \\
\hline Hindu & 2800 & 786 & $28 \cdot 1$ & 540 & 68.7 & 216 & 27.5 & 30 & 3.8 \\
Moslem & 850 & 181 & 21.3 & - & - & 151 & 83.4 & 30 & 16.6 \\
Christian & 50 & 15 & 30.0 & - & - & 5 & 33.3 & 10 & 66.7 \\
\hline
\end{tabular}

$\mathrm{U}-\mathrm{N}=$ uncle-niece. $\mathrm{FC}=$ first cousin. $\mathrm{BYFC}=$ beyond first cousin.

an autosomal recessive trait, had ileal atresia. There were two cases of prune belly syndrome, both of which had bilateral hydronephrosis and a common cloaca. A case of thanatophoric dwarfism and another case of cyclopia had no internal anomalies on necropsy.

The $\chi^{2}$ test was used for statistical analysis.

Table 2 Consanguineous marriages in different socioeconomic groups.

\begin{tabular}{llccc}
\hline & & No & $\%$ \\
\hline Total no of births screened & & 3700 & \\
Total born to lower income group & 2168 & $58 \cdot 6$ \\
Total born to middle/upper income group & 1532 & $41 \cdot 4$ \\
\multicolumn{4}{l}{} \\
\multicolumn{4}{l}{ Lower income } & \multicolumn{3}{c}{ Middle/upper income } \\
Uncle-niece & 350 & $65 \cdot 1 \%$ & 190 & $42 \cdot 8 \%$ \\
First cousin & 178 & $33 \cdot 1 \%$ & 194 & $43 \cdot 7 \%$ \\
Beyond first cousin & 10 & $1 \cdot 8 \%$ & 60 & $13 \cdot 5 \%$ \\
Consanguineous & 538 & $14 \cdot 5 \%$ & 444 & $12 \cdot 0 \%$ \\
Non-consanguineous & 1630 & $44 \cdot 1 \%$ & 1088 & $29 \cdot 4 \%$ \\
\hline
\end{tabular}

Table 3 Effect of consanguinity on congenital malformations.

\begin{tabular}{|c|c|c|c|c|}
\hline & Total & Malformation & $\%$ & $\mathbf{p}$ \\
\hline $\begin{array}{l}\text { Uncle-niece } \\
\text { First cousin } \\
\text { Beyond first cousin } \\
\text { Consanguineous } \\
\text { Non-consanguineous }\end{array}$ & $\begin{array}{r}557 \\
372 \\
70 \\
999 \\
2731\end{array}$ & $\begin{array}{r}52 \\
23 \\
5 \\
80 \\
66\end{array}$ & $\begin{array}{l}9 \cdot 34 \\
6 \cdot 18 \\
7 \cdot 14 \\
8 \cdot 01 \\
2 \cdot 42\end{array}$ & $<0.001$ \\
\hline \multicolumn{3}{|c|}{$\begin{array}{l}\text { No of babies screened } \\
\text { No with congenital anomalies } \\
\text { No of congenital malformations } / 1000 \text { births }\end{array}$} & $\begin{array}{r}3730 \\
146 \\
39 \cdot 1\end{array}$ & \\
\hline
\end{tabular}

\section{Results}

The frequency and type of consanguinity in different religious groups is shown in table 1 . Consanguineous marriages were equally common in the poor and middle/upper class; uncle-niece marriages were the most common in both socioeconomic groups (table 2).

The total incidence of congenital malformations was $39 \cdot 1 / 1000$ births with a significantly higher incidence among the consanguineous group (8.01\%) as compared with the non-consanguineous group $(2.42 \%)(p<0.001)$ (table 3$)$. The incidence of malformations was higher in the uncle-niece matings $(9 \cdot 34 \%)$ as compared with the first cousin marriages $(6.18 \%)(p<0.001)$ (table 3). Malformations of the central nervous, gastrointestinal, musculoskeletal, cardiovascular, and genitourinary systems were significantly higher in the consanguineous group, whereas consanguinity did not seem to have any effect on malformations of the eyes, ears, and skin (table 4). Central nervous system malformations had an unusually high incidence (11·8/1000 births).

Parental consanguinity was present in all the autosomal recessive syndromes seen in our study (Meckel-Gruber syndrome $(n=1)$, variant Waardenburg's syndrome $(n=1)$, cleft lip and lip pit syndrome $(n=1)$, Jeune's asphyxiating thoracic dystrophy $(n=1)$, Ellis-van Creveld syndrome $(n=1)$, diastrophic dwarfism $(n=1)$, congenital adrenal hyperplasia $(n=1)$, and albinism $(n=1))$.

In both socioeconomic groups (poor and middle/ upper), stillbirths were significantly more frequent in the consanguineous group and uncle-niece couples

Table 4 Congenital malformations of different systems in relation to parental consanguinity.

\begin{tabular}{|c|c|c|c|c|c|c|c|}
\hline \multirow[b]{2}{*}{ Malformation } & \multicolumn{2}{|c|}{$\begin{array}{l}\text { Non-consanguineous } \\
(\mathbf{n}=2731)\end{array}$} & \multicolumn{2}{|c|}{$\begin{array}{l}\text { Consanguineous } \\
\qquad(\mathbf{n}=999)\end{array}$} & \multicolumn{2}{|c|}{$\begin{array}{l}\text { Combined } \\
(n=3730)\end{array}$} & \multirow[b]{2}{*}{$\mathbf{p}$} \\
\hline & Total & Incidence & Total & Incidence & Total & Incidence & \\
\hline $\begin{array}{l}\text { Central nervous system } \\
\text { Gastrointestinal tract } \\
\text { Musculoskeletal } \\
\text { Cardiovascular } \\
\text { Skin } \\
\text { Ear } \\
\text { Genitourinary } \\
\text { Eye } \\
\text { Facial } \\
\text { Trisomy } 21 \\
\text { Albinism } \\
\text { Waardenburg's syndrome } \\
\text { Cyclopia } \\
\text { Total }\end{array}$ & $\begin{array}{r}22 \\
7 \\
7 \\
3 \\
9 \\
7 \\
3 \\
3 \\
3 \\
1 \\
- \\
1 \\
66\end{array}$ & $\begin{array}{l}8 \cdot 05 \\
2 \cdot 56 \\
2 \cdot 56 \\
1 \cdot 09 \\
3 \cdot 30 \\
2 \cdot 56 \\
1 \cdot 10 \\
1 \cdot 10 \\
1 \cdot 10 \\
0 \cdot 37 \\
- \\
0.37\end{array}$ & $\begin{array}{r}22 \\
14 \\
13 \\
10 \\
3 \\
2 \\
5 \\
4 \\
4 \\
1 \\
1 \\
1 \\
80\end{array}$ & $\begin{array}{l}22 \cdot 02 \\
14 \cdot 01 \\
13 \cdot 01 \\
10 \cdot 01 \\
3 \cdot 00 \\
2 \cdot 00 \\
5 \cdot 00 \\
4 \cdot 00 \\
4 \cdot 00 \\
1 \cdot 00 \\
1 \cdot 00 \\
1 \cdot 00 \\
-\end{array}$ & $\begin{array}{r}44 \\
21 \\
20 \\
13 \\
12 \\
9 \\
8 \\
7 \\
7 \\
2 \\
1 \\
1 \\
1 \\
146\end{array}$ & $\begin{array}{r}11.8 \\
5.6 \\
5.3 \\
3.5 \\
3.2 \\
2.4 \\
2.1 \\
1.9 \\
1.9 \\
0.5 \\
0.3 \\
0.3 \\
0.3\end{array}$ & $\begin{array}{l}<0.01 \\
<0.01 \\
<0.01 \\
<0.01 \\
<0.05\end{array}$ \\
\hline
\end{tabular}


had a still higher rate compared to first cousin and beyond first cousin couples, irrespective of their socioeconomic status (table 5).

The mean rate of fetal loss per mother in both socioeconomic groups was significantly higher in each of the three types of consanguineous marriages (table 6). However, total fetal losses in previous pregnancies were not analysed separately as abortions and stillbirths, as they were grouped together while recording.

Tables 7, 8, and 9 show the effect of consanguinity on various anthropometric measurements taken at birth. Our study showed a significant decrease in the mean birth weight and head circumference of babies born to consanguineous parents in both the poor and

Table 5 Consanguinity and stillbirths according to socioeconomic status.

\begin{tabular}{|c|c|c|c|c|c|c|c|c|}
\hline \multirow[b]{2}{*}{ Type of union } & \multicolumn{4}{|c|}{ Poor class } & \multicolumn{4}{|c|}{ Upper/middle class } \\
\hline & $\begin{array}{c}\text { Live } \\
\text { births }\end{array}$ & $\underset{\text { births }}{\text { Still }}$ & Total & $\begin{array}{l}\% \text { Still } \\
\text { births }\end{array}$ & $\begin{array}{c}\text { Live } \\
\text { births }\end{array}$ & $\underset{\text { births }}{\text { Still }}$ & Total & $\begin{array}{l}\% \text { Still } \\
\text { births }\end{array}$ \\
\hline $\begin{array}{l}\text { Uncle-niece } \\
\text { First cousin } \\
\text { Beyond first cousin } \\
\text { Consanguineous } \\
\text { Non-consanguineous }\end{array}$ & $\begin{array}{r}290 \\
153 \\
9 \\
452 \\
1550 \\
\chi^{2}=73 \cdot 2, p\end{array}$ & $\begin{array}{r}60 \\
25 \\
1 \\
86 \\
80 \\
1\end{array}$ & $\begin{array}{r}350 \\
178 \\
10 \\
538 \\
1630\end{array}$ & $\begin{array}{r}17 \cdot 1 \\
14 \cdot 0 \\
10 \cdot 0 \\
15 \cdot 9 \\
4 \cdot 9\end{array}$ & $\begin{array}{r}144 \\
165 \\
53 \\
362 \\
966 \\
\chi^{2}=25 \cdot 06\end{array}$ & $\begin{array}{r}46 \\
29 \\
7 \\
82 \\
82 \\
122 \\
001\end{array}$ & $\begin{array}{r}190 \\
194 \\
60 \\
444 \\
1088\end{array}$ & $\begin{array}{l}24 \cdot 2 \\
14 \cdot 9 \\
11 \cdot 7 \\
18 \cdot 5 \\
11 \cdot 2\end{array}$ \\
\hline
\end{tabular}

Table 6 Consanguinity and fetal loss in past and present pregnancies.

\begin{tabular}{|c|c|c|c|c|c|c|c|c|}
\hline & \multicolumn{4}{|c|}{ Poor class } & \multicolumn{4}{|c|}{ Middle/upper class } \\
\hline & $\begin{array}{c}\text { Total } \\
\text { mothers }\end{array}$ & $\begin{array}{c}\text { Total No of } \\
\text { previous } \\
\text { abortions/ } \\
\text { stillbirths }\end{array}$ & $\begin{array}{c}\text { Present } \\
\text { stillbirth }\end{array}$ & $\begin{array}{l}\text { Mortality/ } \\
\text { mother }\end{array}$ & $\begin{array}{c}\text { Total } \\
\text { mothers }\end{array}$ & $\begin{array}{c}\text { Total No of } \\
\text { previous } \\
\text { abortions/ } \\
\text { stillbirths }\end{array}$ & $\begin{array}{c}\text { Present } \\
\text { stillbirths }\end{array}$ & $\begin{array}{c}\text { Mortality/ } \\
\text { mother }\end{array}$ \\
\hline $\begin{array}{l}\text { Uncle-niece } \\
\text { First cousin } \\
\text { Beyond first cousin } \\
\text { Non-consanguineous }\end{array}$ & $\begin{array}{r}350 \\
178 \\
10 \\
1630\end{array}$ & $\begin{array}{r}360 \\
136 \\
8 \\
800\end{array}$ & $\begin{array}{r}60 \\
25 \\
1 \\
80\end{array}$ & $\begin{array}{l}1.2 \\
0.9 \\
0.9 \\
0.5\end{array}$ & $\begin{array}{r}190 \\
194 \\
60 \\
1088\end{array}$ & $\begin{array}{r}163 \\
103 \\
29 \\
422\end{array}$ & $\begin{array}{r}46 \\
29 \\
7 \\
122\end{array}$ & $\begin{array}{l}1 \cdot 1 \\
0 \cdot 7 \\
0 \cdot 6 \\
0.5\end{array}$ \\
\hline
\end{tabular}

Table 7 Effect of consanguinity on birth weight in different soocioeconomic groups.

\begin{tabular}{|c|c|c|c|c|c|c|}
\hline & \multicolumn{6}{|c|}{ Birth weight } \\
\hline & \multicolumn{3}{|c|}{ Poor } & \multicolumn{3}{|c|}{ Middle/upper } \\
\hline & Total & Mean (g) & SEM & Total & Mean (g) & SEM \\
\hline $\begin{array}{l}\text { Uncle-niece } \\
\text { First cousin } \\
\text { Beyond first cousin } \\
\text { Consanguineous } \\
\text { Non-consanguineous }\end{array}$ & $\begin{array}{c}350 \\
178 \\
10 \\
538 \\
1630\end{array}$ & $\begin{array}{c}2765 \\
2774 \\
2750 \\
2763 \\
2800 \\
\mathbf{p}<0.01\end{array}$ & $\begin{array}{l}33 \cdot 2 \\
18 \cdot 6 \\
22 \cdot 4 \\
13 \cdot 2 \\
12 \cdot 1\end{array}$ & $\begin{array}{c}190 \\
194 \\
60 \\
444 \\
1088\end{array}$ & $\begin{array}{c}2887 \\
2883 \\
2883 \\
2884 \\
2987 \\
p<0.01\end{array}$ & $\begin{array}{l}43 \cdot 0 \\
20 \cdot 4 \\
28 \cdot 2 \\
14 \cdot 0 \\
13 \cdot 0\end{array}$ \\
\hline
\end{tabular}

Table 8 Effect of consanguinity on crown-heel length in different socioeconomic groups.

\begin{tabular}{|c|c|c|c|c|c|c|}
\hline & \multicolumn{6}{|c|}{ Crown-heel length } \\
\hline & \multicolumn{3}{|c|}{ Poor } & \multicolumn{3}{|c|}{ Middle/upper } \\
\hline & Total & Mean (cm) & SEM & Total & Mean $(\mathrm{cm})$ & SEM \\
\hline $\begin{array}{l}\text { Uncle-niece } \\
\text { First cousin } \\
\text { Beyond first cousin } \\
\text { Consanguineous } \\
\text { Non-consanguineous }\end{array}$ & $\begin{array}{r}350 \\
178 \\
10 \\
538 \\
1630\end{array}$ & $\begin{array}{c}47 \cdot 1 \\
47 \cdot 2 \\
47 \cdot 4 \\
47 \cdot 2 \\
47 \cdot 6 \\
\mathrm{p}<0 \cdot 01\end{array}$ & $\begin{array}{l}0.12 \\
0 \cdot 16 \\
0.24 \\
0.08 \\
0.09\end{array}$ & $\begin{array}{r}190 \\
194 \\
60 \\
444 \\
1088\end{array}$ & $\begin{array}{c}47 \cdot 8 \\
49 \cdot 0 \\
48 \cdot 2 \\
48 \cdot 3 \\
48 \cdot 2 \\
\text { p=not significant }\end{array}$ & $\begin{array}{l}0 \cdot 26 \\
0 \cdot 16 \\
0 \cdot 27 \\
0 \cdot 10 \\
0 \cdot 09\end{array}$ \\
\hline
\end{tabular}


Table 9 Effect of consanguinity on head circumference in different socioeconomic groups.

\begin{tabular}{|c|c|c|c|c|c|c|}
\hline & \multicolumn{6}{|c|}{ Head circumference } \\
\hline & \multicolumn{3}{|c|}{ Poor } & \multicolumn{3}{|c|}{ Middle/upper } \\
\hline & Total & Mean $(\mathrm{cm})$ & SEM & Total & Mean $(\mathrm{cm})$ & SEM \\
\hline $\begin{array}{l}\text { Uncle-niece } \\
\text { First cousin } \\
\text { Beyond first cousin } \\
\text { Consanguineous } \\
\text { Non-consanguineous }\end{array}$ & $\begin{array}{r}350 \\
178 \\
10 \\
538 \\
1630\end{array}$ & $\begin{array}{c}33.4 \\
33.5 \\
33.5 \\
33.5 \\
33.6 \\
\mathrm{p}<0.05\end{array}$ & $\begin{array}{l}0.14 \\
0.08 \\
0.07 \\
0.05 \\
0.04\end{array}$ & $\begin{array}{r}190 \\
194 \\
60 \\
444 \\
1088\end{array}$ & $\begin{array}{c}33.0 \\
34.0 \\
33.6 \\
33.5 \\
33.9 \\
\mathrm{p}<0.01\end{array}$ & $\begin{array}{l}0.07 \\
0.09 \\
0 \cdot 14 \\
0.07 \\
0.05\end{array}$ \\
\hline
\end{tabular}

middle/upper socioeconomic class. The mean length was less in babies born to consanguineous parents belonging to the poor social class only.

\section{Discussion}

A total of $26.5 \%$ of the total births in the present study was to consanguineous couples. A survey of a very large series of consecutive births in 24 centres around the world showed that the overall frequency of consanguinity was $3 \cdot 7 \%$ and varied from over $30 \%$ in Alexandria to less than $0.1 \%$ in Zagreb; in Bombay it was $10 \% .^{7}$ The summed data for all centres should be interpreted with considerable care as these variations are very large.

Christians, who formed only $1 \cdot 3 \%$ of the study population, had the highest rate of consanguinity $(30 \%)$, mainly because most of them were recent converts to the Christian faith for economic benefits and chose to comply with sociocultural norms that they had practised before their conversion. A high frequency of consanguinity in small isolated communities is well known.

The Hindus, who accounted for $75 \cdot 7 \%$ of the total births, had a consanguinity rate of $28 \cdot 1 \%$, while the Moslems, who accounted for $23 \%$ of the births, had a consanguinity rate of $21 \cdot 3 \%$. Uncle-niece marriage was the most common form of mating (14.5\%), followed by first cousin marriage $(10 \cdot 1 \%)$. The incidence of uncle-niece union in this area is higher than in the neighbouring state of Tamil Nadu $(11 \cdot 2 \%)^{3}$ and also in the neighbouring city of Bangalore $(12 \cdot 5 \%){ }^{8}$ It was most common among the Hindus, accounting for $68.7 \%$ of the consanguineous matings, as against first cousin marriages that were preferred by Hindus in other parts of India. ${ }^{3}$ This preference for uncle-niece marriages seemed to be related to certain sociocultural norms that ensured family stability. Among the Moslems, it was almost obligatory to marry the father's brother's daughter, who is called the 'Bintamm' or first wife, irrespective of her age or time of marriage.

In our study, congenital malformations were significantly higher in consanguineous couples. Studies of congenital malformations in different parts of the world have shown a higher incidence of malformations among consanguineous parents. ${ }^{79}$ Naderi $^{9}$ from Iran observed that the frequency of congenital malformations was $1.66 \%$ of total births in children of nonconsanguineous parents, $4.02 \%$ in children of consanguineous parents, and $2 \cdot 2 \%$ in the total group. In a WHO collaborative study, a higher proportion of the parents of malformed children than of normal infants were consanguineous, and there was a considerable variation in the contribution to the total proportion from different centres. The major contributing centres of malformed infants born to related parents were Alexandria, Bombay, Singapore, Bogota, Medellin, Panama, and Pretoria. These are all areas where the parental consanguinity rate for all births is high. $^{7}$ In contrast to these observations, Rao and Inbaraj ${ }^{3}$ from Tamil Nadu, India showed no significant difference in the offspring of consanguineous and non-consanguineous parents. This difference could possibly result from failure of recognition of malformations of various systems, particularly minor ones and those of the internal organs, by health workers who were employed in that population based study. The difficulties of examining stillbirths, who tend to have higher malformation rates, in adverse field conditions is well known. ${ }^{10}$

In our study, we noted that the malformation rates were significantly higher in uncle-niece marriages compared to first cousin marriages. In Iran, the frequency of malformed children of first cousin marriages was $2.9 \%$ and of children of second cousin marriage was $2.3 \% .^{9}$ Similarly, in Alexandria and Bombay the frequency of malformations was significantly higher in offspring of first cousins and closer relationships than in those related less closely than first cousin. ${ }^{7}$ Thus, it seems probable that the closer the family relationship of the parents, the greater the chances of congenital abnormalities.

The frequency of malformations of major systems in consanguineous couples was significantly higher in our study. Similar observations have been made in other studies. ${ }^{79}$ An interesting feature of our ștudy was an even higher incidence of NTD $(11.8 / 1000)$ as compared to the previously reported high incidence of neural tube defects from north India. ${ }^{11}$ Though there 
is a complex interaction of genetic and environmental factors in the causation of NTD, in our area it is possible that genetic factors may play an important role. $^{12}$

Since inbreeding has been practised in three states of south India (including Karnataka) for more than 2000 years, ${ }^{1}$ the effect of inbreeding, even in so-called non-consanguineous couples in our area, cannot be excluded. The application of more advanced genetic techniques, like DNA fingerprinting, ${ }^{13}$ may unearth more interesting genetic information regarding the effect of inbreeding on fetal growth and development in this highly inbred south Indian population.

There have been conflicting reports on the effects of consanguinity on fetal growth. ${ }^{3}{ }^{14}$ Fetal growth, as assessed by standard anthropometric measurements, is determined by genetic as well as environmental factors. Among the environmental factors, social class, which in turn influences maternal nutrition, ${ }^{15}$ is an important determinant. Hence, an independent analysis of the effect of consanguinity on fetal growth was done separately in the poor and middle/upper socioeconomic classes. Our study showed a significant decrease in the mean birth weight and head circumference of offspring of consanguineous couples in both the poor and middle/upper socioeconomic class. The mean length was less in babies born to consanguineous parents belonging to the poor social class only. Paddaiah and Reddy, ${ }^{14}$ from Andhra Pradesh in south India, observed that inbreeding caused diminution of all anthropometric measurements recorded, but significant differences in anthropometric measurements as related to consanguinity were seen only in the lower socioeconomic class. However, their classification of socioeconomic status into three groups, low, middle, and high income, was arbitrary as it was based on the type of ward the patient was admitted to, paying or non-paying.

A study by Rao and Inbaraj ${ }^{3}$ showed that consanguinity had no effect on fetal growth. The accuracy of this field based population study, which involved health workers with minimal knowledge of health science, needs to be verified, as it involved fetal anthropometric measurements in adverse field conditions and, further, there was no attempt to set the effects of consanguineous marriage against the background of socioeconomic status.

Irrespective of socioeconomic status, stillbirth rates were significantly higher in the consanguineous groups in our study and, further, it was seen that the closer the degree of relationship the higher the stillbirth rate. However, we have no data on perinatal mortality because of our practice of early discharge and poor follow up facilities. Earlier studies have shown that overall mortality in the offspring of consanguineous parents is considerably higher than in those of unrelated parents. ${ }^{79}$ In a WHO collaborative study, ${ }^{7}$ the observed number of stillbirths and liveborn children dying in hospital was higher when the parents were related than when they were not in Bombay, Kuala Lumpur, and Singapore. In the same study, consanguinity being the main determinant of the observed excess mortality in the offspring of related parents is strongly suggested by the summed data and it was also shown that the closer the degree of relationship the higher the mortality. However, in Alexandria, where the consanguinity rates are very high and mortality is also very high, the mortality rate was the same in the offspring of related and unrelated parents. However, no attempt was made in that study to relate the effect of consanguinity to the background of socioeconomic status.

Our study, in conjunction with certain other studies, ${ }^{2} 7914$ shows that consanguinity has, in all probability, a deleterious effect on fetal growth and increases the risk of congenital malformations and fetal loss.

1 Sastri KAN. A history of south India from prehistorical times to fall of Vijayanagar. Madras: Oxford University Press, 1955.

2 Sibert JR, Jadhav M, Inbaraj SG. Fetal growth and parental consanguinity. Arch Dis Child 1979;54:317-9.

3 Rao PSS, Inbaraj SG. Inbreeding effects on fetal growth and development. F Med Genet 1980;17:27-33.

4 Sanghvi ID. Inbreeding in India. Eugen Quart 1966;13:291-301.

5 Marshall WA. Human growth and its disorders. London: Academic Press, 1977:12-21.

6 Prosad BG. Changes proposed in the social classification of Indian families. F Indian Med Assoc 1970;55:198-9.

7 Stevenson AC, Johnston HA, Steward MIP, Golding DR. Congenital malformations - a report of a study of series of consecutive births in 24 centres. Bull WHO 1966;34 (suppl): 1-127.

8 Bittles AH, Appaji Rao N, Radha Rama Devi A. Inbreeding in the state of Karnataka, south India. Hum Hered 1982;32:8-10.

9 Naderi S. Congenital abnormalities in newborns of consanguineous and non-consanguineous parents. Obstet Gynecol 1979;53:195-9.

10 Kulshrestha R, Nath IM, Upadhyaya P. Congenital malformations in liveborn infants in a rural community. Indian Pediatr 1983;20:45-9.

11 Verma IC. High frequency of neural tube defects in north India. Lancet 1978; i:879-80.

12 Kulkarni ML, Mathew MA, Reddy V. The range of neural tube defects in southern India. Arch Dis Child 1989;64:201-4.

13 Jeffreys AJ, Wilson V, Thein SL. Individual specific fingerprints of human DNA. Nature 1985;316:76-9.

14 Paddaiah G, Reddy CG. Effect of consanguinity on anthropometric measurements in the new born. Indian $\mathcal{f}$ Pediatr 1980;47:133-6.

15 Smithells RW, Sheppard S, Schorah CJ. Vitamin deficiencies and neural tube defects. Arch Dis Child 1976;51:944-50. 